3 Macfarlane A, Cole S, Johnson A, Botting B. Epidemiology of birth before 28 weeks of gestation. Br Med Bull 1988;44:861-93.

4 Pharoah POD, Cooke T, Cooke RWI, Rosenbloom L. Birthweight specific trends in cerebral palsy. Arch Dis Child 1990;65:602-6.

5 Stanley FJ, Watson L. Trends in perinatal mortality and cerebral palsy in Western Australia, 1967 to $1985 . B M 7$ 1992;304:1658-63.

6 Scottish Stillbirth and Neonatal Death Repors; 1988 and 1989. Edinburgh: Information and Statistics Division, Scotland, 1991

7 Yu VYH, Loke HL, Bajuk B, Szymonowicz W, Orgill AA, Astbury J. Prognosis for infants born at 23 to 28 weeks' gestation. $B M$ T $^{2} 1986 ; 293$ : $1200-3$.

8 Verloove-Vanhorick SP, Verwey RA, Brand R, Bennebroek Gravenhorst Keirse MJNC, Ruys JH. Neonatal mortality risk in relation to gestationa age and birthweight. Lancet 1986;ii:55-7.

9 Heinonen K, Hakulinen A, Jokela V. Survival of the smallest. Time trends and determinants of mortality in a very preterm population during the 1980 s. Lancet 1988;ii:204-6.

10 Wariyar U, Richmond S, Hey E. Pregnancy outcome at 24-31 weeks' gestation: neonatal survivors. Arch Dis Child 1989;64:678-86.

11 Griffiths R. The abilities of young children. High Wycombe: Association for research in infant and child development, 1970.

12 Henderson S, Sugden DA. Movement assessment battery for children. London: Psychological Corporation, 1992.

13 Egan DF, Brown R. Developmental assessment: 18 months to $4^{12}$ years. The bus puzzle test. Child Care Health and Development 1984;10:163-79.

14 Dennis J, Johnson A, Mutch L, Yudkin P, Johnson P. Acidbase status at birth and neurodevelopmental outcome at four and one-half years. Am $\mathcal{F}$ Obstet Gynecol 1989;161:213-20.

15 Marlow N, Roberts BL, Cooke RWI. Motor skills in extremely low birthweight children at the age of 6 years. Arch Dis Child 1989;64:839-47.

16 Gardner MJ, Gardner SB, Winter PD. Confidence interval analysis. Version 1.1. London: BMJ, 1991
17 Schechner S. For the 1980s: how small is too small? Clinics in Perinatology 1980;7:135-43.

18 Cooke RWI. Outcome and costs of care for the very immature infants. $\mathrm{Br} \mathrm{Med}$ Bull 1988;44:1133-51.

19 Saigal S, Rosenbaum P, Hattersley B, Milner R. Decreased disability rate among 3 year old survivors weighing 501 to 1000 grams at birth and born to residents of a geographically defined region from 1981 to 1984 compared with 1977 to 1980 . I Pediatr 1989;114:839-46.

20 Victorian Infant Collaborative Study Group. Improvement of outcome for infants of birth weight under $1000 \mathrm{~g}$. Arch Dis Child 1991;66:765-9.

21 Saigal S, Rosenbaum P, Stoskopf B, Sinclair JC. Outcome in infants 501 to $1000 \mathrm{gm}$ birth weight delivered to residents of the McMaster health region. f Pediatr 1984;105:969-76.

22 Van-Zeben-van der Aa TM, Verloove-Vanhorick SP, Brand R, Ruys JH. Morbidity of very low birthweight infants at corrected age of two years in geographically defined population. Report from project on preterm and small for gestational age infants in the Netherlands. Lancet 1989;i:253-5.

23 Powell TG, Pharoah POD, Cooke RWI. Survival and morbidity in a geographically defined population of low birthweight infants. Lancet 1986;i:539-44.

24 Chalmers I, Mutch L. Are current trends in perinatal practice associated with an increase or a decrease in handicapping conditions? Lancet 1981 ;i:1415.

25 Aylward GP, Pfeiffer SI, Wright A, Verhulst SJ. Outcome studies of low birth weight infants published in the last decade: a meta analysis. $\mathcal{f}$ Pediat 1989;115:515-20.

26 Scottish Low Birthweight Study: I. Survival, growth, neuromotor and sensor impairment. Arch Dis Child 1992;67:675-81.

27 Paneth N. Neonatal care and patterns of disability in the community. Clinics of Developmental Medicine 1993;123/124:232-4

(Accepted 5 May 1993)

\title{
Can paternal preconceptional radiation account for the increase of leukaemia and non-Hodgkin's lymphoma in Seascale?
}

\author{
L J Kinlen
}

\begin{abstract}
Objective-To determine if the excess of leukaemia and non-Hodgkin's lymphoma in Seascale is restricted to those born in the parish and whether it might be explained by the postulated relation with paternal preconceptional radiation.
\end{abstract}

Design-Comparison, separately for those born in the parish and those born elsewhere, of the numbers of these malignancies observed in Seascale with those expected on the basis of reference rates for England and Wales. Details of paternal radiation levels were sought for each case.

Setting-The parish of Seascale in west Cumbria.

Subjects-Residents of Seascale below age 25 years in the years 1951-91.

Main outcome measures-The observed and expected numbers of cases of leukaemia and nonHodgkin's lymphoma within Seascale among those born there and among those born elsewhere. Also, the levels of any paternal preconceptional radiation associated with each case.

Results-A significant excess of leukaemia and non-Hodgkin's lymphoma at ages 0-24 was found in Seascale in those who were born there (ratio of observed to expected cases 8.6 and 20.2 respectively; $p<0 \cdot 01)$. This also applied to those not born there $(7.2$ and $16.5 ; p<0.01)$, a group often regarded as not showing an excess. The estimates were then conservatively recalculated so as to overestimate the risks among those born in Seascale and underestimate them among those born elsewhere. On this basis the six cases in those born in Seascale compare with 0.38 expected $(15.8 ; p<0.001)$, of which two were associated with paternal preconceptional lifetime levels of $100 \mathrm{mSv}$ or greater and three others with levels of $90-99 \mathrm{mSv}$. Among those born elsewhere, there were five cases (expected 0.74 ; ratio $6.7, p<0.01$ ), of which only one was associated with a high level of such radiation.

Conclusions-Paternal preconceptional radiation cannot be the sole cause of the excess in Seascale since it will not explain the excess among those born outside Seascale. It follows that, unless two causes are to be postulated, any single cause must be a factor other than paternal preconceptional radiation. On this basis, the association found among those born there, if not partly due to chance, may reflect an indirect relation with the true cause. The recent hypothesis about such paternal radiation has originated in a subgroup of the excess cases that have aroused concern.

\section{Introduction}

An increased incidence of leukaemia and nonHodgkin's lymphoma among young people in Seascale near the nuclear site of Sellafield in west Cumbria has been the subject of much study. Recent work has further strengthened the evidence of an excess, indicating its magnitude as well as its persistence into a recent period. ${ }^{1}$ The suggested explanation for this excess attracting most attention is that concerning paternal preconceptional exposure to relatively high levels of radiation. ${ }^{2}$ This association with leukaemia, which emerged from a study restricted to young people born in west Cumbria, is postulated to be causal and also to explain the excess in Seascale. ${ }^{2}$ In fact, the relevant paternal exposure details have been reported only for those children born in Seascale-because no excess was considered to be present in young people who were born elsewhere. ${ }^{34}$ However, this view has been questioned, and the need for paternal details in cases of these malignancies among those born outside Seascale has been emphasised. ${ }^{5}$ These aspects are examined here.

\section{Methods}

\section{LEUKAEMIA AND NON-HODGKIN'S LYMPHOMA}

Cases of leukaemia and non-Hodgkin's lymphoma recurring below age 25 in Seascale from 1951 to 1991 were identified. The particulars of cases up to 1983 which are listed in the report of the Black Advisory Group $^{6}$ have been supplemented by details obtained 
from a national series of death certificates, from relevant birth certificates, and from local clinicians. Cases diagnosed since $1983^{1}$ have also been included.

SEASCALE POPULATIONS

Population details by five year age group up to age 24 for Seasacle parish were obtained from the Office of Population Censuses and Surveys in the form of unpublished tables for the census years 1961, 1971, 1981 , and 1991 . The only age group below age 25 for which a 1951 census count is available is $0-14$ years (383). Records of the local authority school in Seasacle showed 181 children aged 5-15 on the roll for that year and this has been taken as approximating to the number of residents aged 5-14 years, implying a population of about 202 for the 0-4 age group. The proportion of the 1951 population aged 5-14 that were aged 5-9 and also the population aged 15-19 and 20-24 were derived using the levels recorded in these age groups in the three subsequent censuses. The age specific populations in intercensal years were derived by linear interpolation. In this way person years by age group could be assembled for 1951-5 and for subsequent quinquennia to $1981-5$ and also for the final period 1986-91.

For children born in Seascale, populations by single years of age and single calendar years were estimated by using details of the numbers of births to residents in the years 1950-83 and of moves from the parish by members of this cohort by age and calendar period reported in a previous study. ${ }^{7}$ For the years before 1949 and after 1983 the numbers of births were assumed to be low-three per year before 1950 (when the school roll showed an average of around 40 children aged 5-15) and 15 per year after 1983 . The levels of outward

TABLE I-Leukaemia in young people in Seascale: observed and expected numbers by age group and calendar period 1951-91

\begin{tabular}{|c|c|c|c|c|c|c|c|}
\hline Age group & $1951-60$ & 1961-70 & $1971-80$ & 1981-91 & Total & $\begin{array}{l}\text { Ratio of observed } \\
\text { to expected cases }\end{array}$ & p Value \\
\hline \multicolumn{8}{|c|}{ Cases among those born in Seascale (expected values in parentheses are underestimates) } \\
\hline $\begin{array}{c}0-4 \\
5-9 \\
10-14 \\
15-19 \\
20-24\end{array}$ & $\begin{array}{l}1(0.04) \\
0(0.01) \\
0(0.00) \\
0(0.00) \\
0(0.00)\end{array}$ & $\begin{array}{l}1(0.05) \\
0(0.02) \\
0(0.01) \\
0(0.00) \\
0(0.00)\end{array}$ & $\begin{array}{l}1(0.04) \\
1(0.02) \\
0(0.01) \\
0(0.01) \\
0(0.00)\end{array}$ & $\begin{array}{l}0(0.04) \\
0(0.02) \\
0(0.01) \\
0(0.01) \\
0(0.01)\end{array}$ & $\begin{array}{l}3(0.17) \\
1(0.07) \\
0(0.03) \\
0(0.02) \\
0(0.01)\end{array}$ & & \\
\hline $0-24$ & $1(0.05)$ & $1(0.09)$ & $2(0.09)$ & $0(0.09)$ & $4(0.31)$ & $12 \cdot 9$ & $<0.001$ \\
\hline
\end{tabular}

\begin{tabular}{cccccccc}
\multicolumn{7}{c}{ Cases among those born outside Seascale (expected values in parentheses are overestimates) } \\
$0-4$ & $0(0.06)$ & $0(0.05)$ & $0(0.04)$ & $0(0.02)$ & $0(0.018)$ & & \\
$5-9$ & $1(0.04)$ & $0(0.05)$ & $0(0.04)$ & $0(0.02)$ & $1(0.15)$ & & \\
$10-14$ & $0(0.02)$ & $1(0.03)$ & $0(0.03)$ & $0(0.02)$ & $1(0.11)$ & & \\
$15-19$ & $0(0.01)$ & $0(0.02)$ & $0(0.03)$ & $1(0.03)$ & $1(0.09)$ & & \\
$20-24$ & $0(0.01)$ & $0(0.01)$ & $0(0.02)$ & $0(0.01)$ & $0(0.05)$ & & \\
\hline $0-24$ & $1(0.15)$ & $1(0.16)$ & $0(0.16)$ & $1(0.11)$ & $3(0.58)$ & 5.2 & $<0.05$ \\
\hline
\end{tabular}

TABLE II-Non-Hodgkin's lymphoma in young people in Seascale: observed and expected numbers by age group and calendar period 1951-91

\begin{tabular}{llllll}
\hline Age group & $1951-60$ & $1961-70$ & $1971-80$ & $1981-91$ & Total
\end{tabular} $\begin{aligned} & \text { Ratio of observed } \\
& \text { to expected cases p Value }\end{aligned}$

\begin{tabular}{cccccccc}
\hline \multicolumn{7}{c}{ Cases among those born in Seascale (expected values in parentheses are underestimates) } \\
$0-4$ & $1(0.005)$ & $0(0.01)$ & $0(0.00)$ & $1(0.00)$ & $2(0.02)$ & \\
$5-9$ & $0(0.00)$ & $0(0.01)$ & $0(0.01)$ & $0(0.00)$ & $0(0.02)$ & \\
$10-14$ & $0(0.00)$ & $0(0.00)$ & $0(0.00)$ & $0(0.00)$ & $0(0.01)$ & \\
$15-19$ & $0(0.00)$ & $0(0.01)$ & $0(0.00)$ & $0(0.01)$ & $0(0.01)$ & & \\
$20-24$ & $0(0.00)$ & $0(0.00)$ & $0(0.00)$ & $0(0.01)$ & $0(0.01)$ & & \\
\hline $0-24$ & $1(0.01)$ & $0(0.02)$ & $0(0.02)$ & $1(0.02)$ & $2(0.07)$ & 28.5 & $<0.01$ \\
\hline
\end{tabular}

\begin{tabular}{cccccccc}
\multicolumn{7}{c}{ Cases among those born outside Seascale (expected values in parentheses are overestimates) } & . \\
$0-4$ & $0(0.01)$ & $0(0.00)$ & $0(0.00)$ & $0(0.00)$ & $0(0.02)$ & & \\
$5-9$ & $0(0.01)$ & $0(0.01)$ & $0(0.01)$ & $1(0.00)$ & $1(0.03)$ & & \\
$10-14$ & $0(0.01)$ & $0(0.01)$ & $0(0.01)$ & $0(0.01)$ & $0(0.03)$ & & \\
$15-19$ & $0(0.00)$ & $0(0.01)$ & $0(0.01)$ & $0(0.01)$ & $0(0.04)$ & & \\
$20-24$ & $0(0.00)$ & $0(0.01)$ & $0(0.01)$ & $1(0.01)$ & $1(0.03)$ & & \\
\hline $0-24$ & $0(0.03)$ & $0(0.05)$ & $0(0.05)$ & $2(0.03)$ & $2(0.16)$ & 12.5 & $<0.05$ \\
\hline
\end{tabular}

movement from Seascale among those born there were taken to be slightly higher than those reported, thereby reducing the estimated numbers of those still resident there. These were calculated by rounding the fractions of those remaining in Seascale in each quinquennial calendar period in each age group (derived from table $\mathrm{IVb}$ in reference 7 ) downwards to the nearest 0.05 (for example, 0.79 became 0.75 and 0.74 became 0.70 ). More importantly, it was assumed that the percentage who left at, say, ages $0-4$ all migrated below age 1 . To further underestimate the populations in each single year of age and single calendar year, only the integer part of each number was used (for example, 12.9 was treated as 12).

Population estimates for those born elsewhere were derived by subtracting the details of those born in Seascale from the estimates for all residents of the parish. Because the numbers of those born within Seascale had been underestimated, the estimates for those born elsewhere would tend to be inflated, as would the corresponding expected numbers. Erring on the side of exaggerating the expected numbers for the group of special interest, namely those born elsewhere, ${ }^{5}$ would lead to a conservative estimate of any excess in this group. As a check on this method it was applied to the births in the years $1950-83$ covered in the earlier study. ${ }^{7}$ Following up this group until mid-1986 by this method yielded a value of 7548 person years during residence in Seascale-appropriately smaller numbers than those published (8711).

\section{EXPECTED NUMBERS}

The numbers of cases of leukaemia and nonHodgkin's lymphoma observed in Seascale from 1951 to 1991 were compared with the numbers that would be expected. Expected numbers were calculated by applying national reference rates by age group and quinquennium to the corresponding population estimates for Seascale residents who were born there. A similar procedure was carried out for Seascale residents who were born outside the parish. For the period 196291, incidence rates for England and Wales from the national register of childhood cancers for ages 0-4, 5-9 and 10-14 and from the national cancer registration scheme for ages 15-19 and 20-24 were used. (Because of concern about incomplete registration of cases in those national schemes in the recent period it was judged prudent to use the rates for 1981-5 also for the period 1986-91.) For the earlier years 1951-61, for which reliable incidence data are not available, the corresponding national mortality rates were used both because incidence rates are not available for that period and because these malignancies were nearly always fatal.

\section{RADIATION DETAILS}

For the fathers of all individuals with leukaemia or non-Hodgkin's lymphoma, details were sought from the relevant nuclear bodies of any radiation exposures at Sellafield or elsewhere before the relevant conception, taken as 266 days ( 38 weeks) before the date of birth.

\section{Results}

The observed and expected numbers of leukaemia and non-Hodgkin's lymphoma in Seascale by age group and calendar period are shown in tables I and II, separately for those born in the parish and for those born outside. The use of different methods for estimating the age specific population for 1951 (consistent with the published census figure for the age group 0-14) had little effect on the expected numbers. No non-fatal case of either malignancy occurred in the years 1951-61, when national mortality was used as the 
standard. There was a significant excess of leukaemia over the period 1951-91 both among those born in Seascale $(4 v 0.31$ expected; ratio $12.9, \mathrm{p}<0.001)$ and also in those born elsewhere $(3 v 0.58 ; 5.2, \mathrm{p}<0.05)$ (table I). There was also a significant excess of nonHodgkin's lymphoma both among those born in Seascale $(2 v 0.07 ; 28.5, \mathrm{p}<0.01)$ and among those born elsewhere $(2 v 0.16 ; 12.5, \mathrm{p}<0.05)$. If these expected numbers were not deliberately underestimated in those born in Seascale nor overestimated in the others (see Methods) then the observed to expected ratios for leukaemia become respectively $8.6(p<0.01)$ and $7.2(p<0.01)$. For non-Hodgkin's lymphoma the corresponding ratios are $20.2(\mathrm{p}<0.01)$ and 16.5 $(p<0.01)$. All but one of the five born outside Seascale were born outside west Cumbria.

Details of the radiation exposures of the fathers of these young people before their conception are shown in table III, which uses the categories used by Gardner and his colleagues. ${ }^{2}$ For completeness, corresponding details are shown for other malignancies as included in the recent study of Draper et al. ${ }^{1}$ The cases of leukaemia and non-Hodgkin's lymphoma are far from confined to the subgroup associated with lifetime preconceptional radiation levels of $100 \mathrm{mSv}$ or morethe dosage category found to be associated with an increased relative risk of 8.3 for leukaemia and nonHodgkin's lymphoma. ${ }^{2}$ Of a total of 11 cases diagnosed while resident in Seascale, only three were associated with such high levels (though a further three had levels

TABLE III-Details of birthplace and paternal radiation in people aged 0-24 with malignancy who were resident in Seascale at diagnosis

\begin{tabular}{|c|c|c|c|c|c|c|}
\hline $\begin{array}{l}\text { Case No } \\
\text { (Draper } \\
\text { et al })\end{array}$ & $\begin{array}{l}\text { Year of } \\
\text { diagnosis }\end{array}$ & Age & $\begin{array}{l}\text { Born in } \\
\text { Seascale }\end{array}$ & Diagnosis & $\begin{array}{c}\text { Paternal } \\
\text { radiation } \\
\text { category } \\
(\mathrm{mSv})\end{array}$ & $\begin{array}{c}\text { Reference No } \\
\text { in Black } \\
\text { report }\end{array}$ \\
\hline 1 & 1954 & 6 & No & Neuroblastoma & 0 & 22 \\
\hline 2 & 1955 & 7 & No & Acute lymphatic leukaemia & 0 & 1 \\
\hline$t$ & 1955 & 2 & Yes & Non-Hodgkin's lymphoma & 0 & 14 \\
\hline 3 & 1960 & 2 & Yes & Acute myeloid leukaemia & $50-99^{-}$ & 3 \\
\hline 4 & 1968 & 11 & No & Acute lymphatic leukaemia & $0 \cdot 1-49^{n}$ & 2 \\
\hline 5 & 1968 & 4 & Yes & Acute lymphatic leukaemia & $\geqslant 100$ & 5 \\
\hline 6 & 1971 & 2 & Yes & Acute lymphatic leukaemia & $\geqslant 100$ & 6 \\
\hline 7 & 1975 & 15 & Yes & Rhabdomyosarcoma & 0 & 26 \\
\hline 8 & 1979 & 5 & Yes & Acute lymphatic leukaemia & $50-99^{\circ}$ & 7 \\
\hline 9 & 1983 & 9 & No & Non-Hodgkin's lymphoma & 0 & 16 \\
\hline 10 & 1984 & 1 & Yes & Non-Hodgkin's lymphoma & $50-99^{2}$ & 17 \\
\hline 11 & 1985 & 18 & No & Pinealoma & $0 \cdot 1-49$ & NA \\
\hline 12 & 1988 & 23 & No & $\begin{array}{l}\text { Non-Hodgkin's lymphoma } \\
\text { (Burkitt-like lymphoma) }\end{array}$ & $\geqslant 100$ & NA \\
\hline 13 & 1988 & 17 & Yes & Hodgkin's disease & $0 \cdot 1-49^{4}$ & NA \\
\hline 14 & 1991 & 16 & No & Acute lymphatic leukaemia & 0 & NA \\
\hline $15 \ddagger$ & 1978 & 19 & Yes & Chronic myeloid leukaemia & $\geqslant 100$ & 4 \\
\hline$\$ \neq$ & 1954 & 3 & Yes & Subacute lymphatic leukaemia & 0 & NA \\
\hline
\end{tabular}

a $=$ in range $90-99 \mathrm{mSv} ;{ }^{b}=5.5 \mathrm{mSv} ;{ }^{\mathrm{c}}=5 \mathrm{mSv} ;{ }^{\mathrm{d}}=0.5 \mathrm{mSv}$

$\mathrm{NA}=$ Not applicable (diagnosed subsequently, etc)

* $=$ Not applicable (diagnosed subsequently, etc).

tInadvertently omitted initially and reported subsequently.'

†Diagnosed a few months after leaving Seascale for another address.

$\ddagger$ Diagnosed a few months after lea
§This case given by Gardner $e t$ al.

TABLE IV-Leukaemia and non-Hodgkin's lymphoma in Seascale residents aged 0-24 years: numbers observed by paternal preconceptional radiation levels in those born in Seascale and those born elsewhere

Paternal preconceptional radiation

level (lifetime; $\mathrm{mSv}$ ) Leukaemia NHL Leukaemia and NHL Expected No p Value

\begin{tabular}{llclll}
\hline & \multicolumn{5}{c}{ Born in Seascale } \\
Unexposed & $0^{\star}$ & 1 & 1 & \\
$0 \cdot 01-49 \cdot 9$ & 0 & 0 & 0 & \\
$50-99 \cdot 9$ & 2 & 1 & 3 & \\
$>100$ & $2^{\star}$ & 0 & 2 & 0.37 & $<0.001$ \\
Total & 4 & 2 & 6 & 1
\end{tabular}

\begin{tabular}{|c|c|c|c|c|c|}
\hline \multicolumn{6}{|c|}{ Born elsewhere } \\
\hline Unexposed & 2 & 1 & 3 & & \\
\hline $0.01-49 \cdot 9$ & 1 & 0 & 1 & & \\
\hline $50-99 \cdot 9$ & 0 & 0 & 0 & & \\
\hline$>100$ & 0 & 1 & 1 & & \\
\hline Total & 3 & 2 & 5 & 0.74 & $<0.01$ \\
\hline All residents & 7 & 4 & 11 & $1 \cdot 11$ & $<0.001$ \\
\hline
\end{tabular}

*In each of these categories there is an additional individual who developed leukaemia within a few months of leaving Seascale for another address. in the range $90-99 \mathrm{mSv}$ ). It is only if attention is restricted to those born in Seascale that a definite association with high levels of preconceptional radiation appears-shown by five of the six cases (table III). In contrast, in only one of the five cases among those born elsewhere is such an association present. Among the other four, only one father (of case No 4,1 shown in table III) was recorded as having any radiation exposure before the relevant conceptionnamely, a lifetime preconceptional dose of $5.5 \mathrm{mSv}$, none of which was in the six months before conception. All radiation details given in the tables refer to external doses, as in the original study. ${ }^{2}$ Inclusion of internal doses made only small absolute differences, though it moved one individual from the range $90-99 \mathrm{mSv}$ to over $100 \mathrm{mSv}$.

Table IV summarises these details of leukaemia and non-Hodgkin's lymphoma. It would have been inappropriate to include in tables I, II, and IV the two cases of leukaemia that were diagnosed a few months after leaving Seascale. One is the case discovered in the birth cohort study in a child born in 1950 who died in 1954 aged 3.5 The second was diagnosed at age 19 in 1978 but, as was recently pointed out, ' was innacurately included in the Black report and also in the casecontrol study ${ }^{2}$ as a Seascale case. Details of these cases are shown in parentheses in table III. The first child died of leukaemia within five months of being registered in the NHS central register at an address away from Seascale, and the other within two months of such a change. Nevertheless these two cases associated with Seascale undoubtedly represent an excess and are therefore relevant to the overall picture of those malignancies in relation to this parish: even if all those who were born in Seascale in the years 1940-91 had left Seascale (after 1951) they would contribute, in the first six months after leaving, only about 600 person years. It can be deduced from the fact that the 8816 person years (among those born in Seascale) yielded an expected value of 0.31 , that the expected numbers of cases of leukaemia based on 600 person years would be tiny. Of those two cases, one was associated with a paternal preconceptional radiation level above $100 \mathrm{mSv}$; the father of the other had not been exposed to radiation.

\section{Discussion}

This study shows that, despite the not infrequent assertions to the contrary, a significant excess of leukaemia and non-Hodgkin's lymphoma in Seascale is not restricted to young people who were born there. It was among these that the hypothesis largely originated about paternal preconceptional radiation and the subsequent risk of leukaemia and non-Hodgkin's lymphoma in their children. ${ }^{2}$ The present findings also indicate that high levels of such radiation cannot explain the significant excess among young people who moved into the parish.

Our findings for Seascale residents who were born elsewhere may seem to conflict with the reported absence of any excess of these malignancies among children born elsewhere but attending schools in Seascale. ${ }^{3}$ A discrepancy is apparent, however, only if certain facts are overlooked. The previous study was not restricted to Seascale but to a group of individuals who were followed from a point when they attended school in that parish to a fixed point (mid-1986) when some had reached age 35, and long after many of them had moved away from Seascale. No less than $46 \%$ of those born outside Seascale who attended the local authority (the main) school had moved again (out of the parish) before reaching the age of 11 years. ${ }^{3}$ Inevitably, therefore, an appreciable contribution to the expected values for leukaemia and non-Hodgkin's lymphoma 
came from periods spent outside Seascale. Furthermore, the expected numbers that were estimated for these malignancies $(0 \cdot 7)$ referred only to deaths. The only death (in 1956; case No 1 in the Black report) in a child born in 1947 was excluded as the study covered only children born since 1950 . There were, however, also two non-fatal cases (case Nos 2 and 16 in the Black report $^{6}$ ), and a further two cases (case Nos 12 and 14 in Draper $e t a l^{4}$ ) have occurred more recently, both in people born outside Seascale.

The large scale of movement out of Seascale is a feature also of the children who were born there, $40 \%$ of whom did not stay long enough to attend a local school at the age of 4 or 5 -similar to the proportion of parents coming off the electoral register within five years of their child's birth. ${ }^{7}$ Almost all the cases of leukaemia and non-Hodgkin's lymphoma among young people born in Seascale have occurred while they were living there. The only two exceptions (both leukaemia) were diagnosed within a few months of the children moving away. (The corresponding expected value cannot be calculated precisely for this period, but it is most unlikely to have been more than 0.05 ; $\mathrm{p}<0.01$.)

The calendar period covered by the present study (1951-91) is wider than that analysed in the recent study by Draper and his colleagues (1963-90 for ages 014, 1969-90 for ages 15-24). ${ }^{1}$ For the latter periods, the present study found closely similar incidence rates to theirs, in keeping with the similar methods for calculating the populations: for the entire study period, the age standardised annual incidence for leukaemia (all types) and non-Hodgkin's lymphoma was $412 \cdot 4$ per million at ages $0-14$ and 218.9 per million at ages 15-24.

Exposures in the high external radiation category occurred only to the fathers of three of the 11 cases in Seascale (or four of 13 if the cases associated with Seascale are included). Even if inspection of the data is allowed to widen the definition of high exposure from $100 \mathrm{mSv}$ to $90 \mathrm{mSv}$ or over, such cases represent only about half the total-namely, six out of 11 , or seven out of 13 if the associated cases are included. If the remaining five cases without appreciable paternal preconceptional radiation had been the only cases in Seascale, they would still have represented a significant excess (expected $1.09, \mathrm{p}<0.01$ ) and clearly one that cannot be explained on the basis of such radiation. A different explanation must therefore be invoked for these cases. Suggested explanations for the overall excess in Seascale include some unidentified chemical leukaemogen ${ }^{9}$ and an (infective) epidemic promoted by the unusual population mixing in an isolated area of high social class, ${ }^{10}$ though only for the latter does any independent evidence exist. ${ }^{10-14}$ While it is possible that two separate causes of leukaemia and non-Hodgkin's lymphoma have operated in Seascale, the appeal to scientific parsimony of searching for a single cause cannot lightly be dismissed.

The suggestion that paternal preconceptional radiation could explain the excess of leukaemia and non-Hodgkin's lymphoma in Seascale ${ }^{2}$ is not supported by the present study. If there is a single dominant cause for this excess, the association shown by a subgroup with paternal preconceptional radiation, unless partly due to chance, points to an indirect (or conceivably an interactive) relation with the true cause. Some commonality with the excess near Britain's other large remote nuclear site at Dounreay has been strongly suggested, ${ }^{15}$ so that the absence of any association there with paternal radiation ${ }^{1416}$ makes an interactive relation ${ }^{17}$ most unlikely. If it had been clear from the outset that the association with paternal preconceptional radiation was present only in a subgroup of the excess cases, this association must inevitably have seemed less striking since hypotheses with such a basis are well known often to be unreliable.

I am grateful to Dr A Slovak, chief medical officer, British Nuclear Fuels, and Dr G Green, chief medical officer, Atomic Energy Authority Technology, for details of paternal radiation exposures; Charles Stiller and the Childhood Cancer Research Group for incidence rates at ages 0-14; the Office of Population Censuses and Surveys for cancer incidence rates at ages 15-24 for the period 1962-85; Ms Janette Wallis for clerical help; and Ms Sally Price for secretarial help.

1 Draper GJ, Stiller CA, Cartwright RA, Craft AW, Vincent TJ. Cancer in Cumbria and in the vicinity of the Sellafield nuclear installation, 1963-90. Cumbria and in the

2 Gardner MJ, Snee MP, Hall AJ, Powell CA, Downes S, Terrell JD. Results of case-control study of leukaemia and lymphoma among young people near Sellafield nuclear plant in West Cumbria. BM7 1990;300:423-9.

3 Gardner MJ, Hall AJ, Downes S, Terrell JD. Follow up study of children born elsewhere but attending school in Seascale, West Cumbria (schools cohort). BMF 1987;295:819-22

4 Gardner MJ, Snee MP. Leukaemia and lymphoma among young people near Sellafield. BMY 1990;300:678.

5 Kinlen LJ. Leukaemia and lymphoma among young people near Sellafield. $B M 7$ 1990;300:677.

6 Black D. Investigation of the possible increased incidence of cancer in West Cumbria. Report of the Independent Advisory Group. London: HMSO, 1984

7 Gardner MJ, Hall AJ, Downes S, Terrell JD. Follow up study of children born to mothers resident in Seascale, West Cumbria (birth cohort). BMF 10 mothers resider

8 Draper GJ, Stiller CA, Cartwright RA, Craft AW, Vincent TJ. Correction: Cancer in Cumbria and in the vicinity of the Sellafield nuclear installation, 1963-90. BM71993;306:761.

9 Evans HJ. Leukaemia and radiation. Nature 1990;345:16-7.

10 Kinlen L. Evidence for an infective cause of childhood leukaemia: comparison of a Scottish new town with nuclear reprocessing sites in Britain. Lancet 1988;ii: $1323-7$.

11 Kinlen LJ. Evidence from population mixing in British new towns 1946-85 of an infective basis for childhood leukaemia. Lancet 1990;336:577-82.

12 Kinlen LJ, Hudson C, Stiller C. Contacts between adults as evidence for an infective origin of childhood leukaemia: an explanation for the excess near nuclear establishments in West Berkshire? Br f Cancer 1991;64:549-54

13 Kinlen LJ Hudson C. Childhood leukaemia and poliomyelitis in relation to military encampments in England and Wales in the period of national military encampments in England and Wales

14 Kinlen LJ, O'Brien F, Clarke K, Balkwill A, Matthews F. Rural population mixing and childhood leukaemia: effects of the North Sea oil industry in mixing and childhood leukaemia: effects of the North Sea oil industry in
Scotland, including the area near Dounreay nuclear site. $B M \mathcal{F} 1993 ; 306$ : $743-8$

15 Committee on the Medical Aspects of Radiation in the Environment. Second Reporr. Investigation of the possible increased incidence of leukaemia in young people near the Dounreay Nuclear Establishment, Caithness, Scotland. London: HMSO, 1988

16 Urquhart JD, Black RJ, Muirhead MJ, Sharp L, Maxwell M, Eden OB, et al. Case-control study of leukaemia and non-Hodgkin's lymphoma in children in Caithness near the Dounreay nuclear installation. BM7 1991;302:687-92.

17 Greaves MF. The Sellafield childhood leukaemia cluster: are germline mutations responsible? Leukaemia 1990;4:391-6.

(Accepted 15 April 1993)

\section{ONE HUNDRED YEARS AGO}

\section{"WE CALL IT SUBSTITUTION."}

Several grocers were fined last week for selling "substitutes" for coffee and chicory without a label attached. There is something peculiarly pleasing about this word "substitute," and honest withal, for it is a confession that adulteration of the old style is going out of fashion; we no longer let things down with sand or water or what not, but we substitute some entirely different compound. Brewers have long thriven on the scientific use of substitutes for malt, and all forms of adulteration of butter paled before the simple plan of selling margarine in its stead. Obviously, now that margarine has obtained a legal footing, what is wanted is a "substitute" for margarine, and no doubt it will come before long. Coffee seems already to have arrived at that second stage in its downward progress; it is bad enough to buy it adulterated with chicory, but now we find this itself replaced by a "substitute" which goes by the name of "German chicory."

(BM7 1893;ii:141) 